\title{
Homemade bombs and heavy urogenital injuries create new medical challenges
}

Previously published at www.cmaj.ca

$\mathrm{F}$ rom a battle zone in Iraq and a United States military hospital in Germany, where the wounded of two wars intersect, Dr. Rodney Davis treated fighters who surely would not have survived in any other time and place.

One was a Marine who needed an astonishing 85 units of blood, and all the drugs that doctors in the zone could rustle up. Another was an Army soldier, a young man on a fast track to US citizenship, who lost both legs, one arm, his other hand and a testicle in a bomb blast.

Thanks to modern medicine, armour, supply and evacuation chains, communication and tactics, those men and many other Afghanistan and Iraq veterans have escaped death. But with those successes, doctors - urologists prime among them - are confronting daunting challenges they've not faced before.

They are seeing injuries and longterm trauma they don't always know how to treat because, in the past, such soldiers never would have made it off the battlefield.

"Sometimes you wonder what you're sending back to the family," says Davis, now urology chief for the federal Tennessee Valley veterans health care system and a urology professor at Vanderbilt University, both in Nashville. "We save a lot of people out there but we send people home who have dramatically changed."

Brain trauma and lost limbs are the signature injuries of war in Afghanistan and Iraq as soldiers clad in body armour fight adversaries who use homemade bombs. In such a conflict, extremities are obviously at the most risk. Less obvious is an emerging range of conditions becoming known as "urotrauma."

Legislation has been introduced in the US Congress to have the government study urotrauma, loosely defined as injury to the genitourinary system pri-

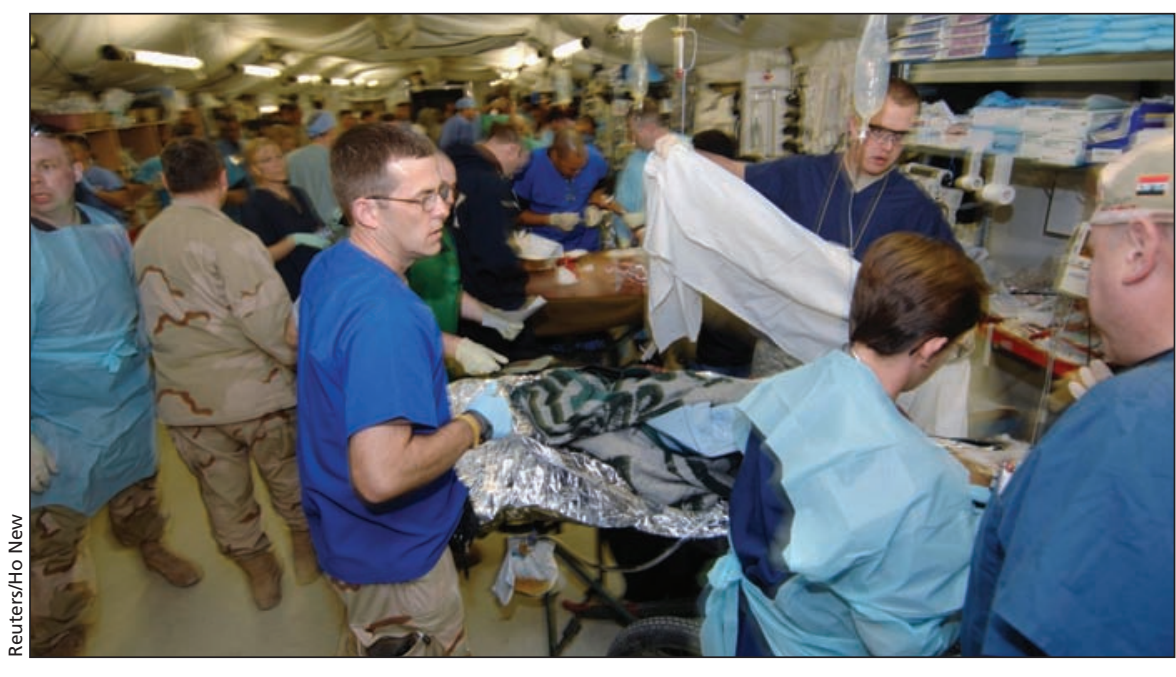

United States military personnel with the 332nd Expeditionary Medical Group treat trauma patients at the Air Force Theater Hospital on Balad Air Base in Iraq. Army Lt. Col. Donald Robinson said injuries caused by improvised explosive devices were unlike anything seen in combat before and posed constant challenges for field surgery specialists in the conflict dubbed the "Super Bowl of Trauma."

marily from explosives. Also of concern: abdominal muscle strain, sometimes leading to pelvic prolapse, from bearing the heavy weight of armour and gear.

Such a study would carry research well beyond battlefield wounds to cast more light on sexual dysfunction, infertility, urinary tract problems and related conditions that can plague veterans.

"This is affecting young men and women who are going into battle in a way that is new and different to us, and coming home with debilitating injuries," says Beth Kosiak, associate executive director of health policy at the American Urology Association (AUA). "There really isn't an idea of how to treat the complex conditions these people face. We don't have a body of literature here."

The bill, introduced in the House of Representatives in April with the AUA's authorship, sought to establish a multiagency national commission led by the Defense Department to analyze the prevalence of urotrauma in the armed forces and improve treatment. It proposed US\$4 million for the task over four years. The bill has since been condensed and incorporated into sweeping military-budget legislation to be voted on later this year.

Neither American nor Canadian military leaders have a grasp on the incidence of urotrauma in their active troops and veterans, in part because it is not fully established as a distinct category of injury. The Department of National Defence, however, says about $7.5 \%$ of Canadian Forces casualties have suffered some form of urogenital trauma, which may include damage to the kidney, ureter, bladder, penis or urethra.

Many of the urogenital injuries that one Canadian doctor has seen at field hospitals in Afghanistan involve kidney injuries that can be treated without surgery. But Lieutenant-Colonel Dr. Homer Tien has also seen "fairly benign" penile or scrotal trauma on Canadian soldiers, where pieces of shrapnel have gone through the scrotum and are treated as any penetrating injury, he says.

"Amongst non-Canadian soldiers, I've seen worse," says Tien, a surgeon 
with the trauma program at the Sunnybrook Health Sciences Centre in Toronto, Ontario, when not serving as National Practice Leader — Trauma with the Canadian Forces Health Services. "I've seen fairly devastating penile or scrotal injuries, often associated with IEDS [improvised explosive devices] blowing up below them."

In the US, the AUA monitors what urologists abroad and at home are reporting, and has been told anecdotally that more than $12 \%$ of war injuries involve genitourinary trauma, says Kosiak, who testified at a House hearing on the matter. "There are some urologists who are saying, 'I'm seeing this, and I'm not seeing a way of helping these patients short of getting them off the battlefield'."

She says two reviews, one using data back to 1960, the other an indepth analysis of the US army's trauma registry over the last year, did not yield useful information on injuries to specific genitourinary organs or treatments used.

Davis has encountered the effects at all stages: fresh battle wounds in Iraq's Anbar province; severe injuries at the US military hospital in Landstuhl, Germany; and now chronic ailments and long-term recoveries at his veterans department post in Tennessee.

He thinks often of the Mexican soldier he cared for in Germany and wonders what kind of life a veteran can have after suffering not only lost limbs but the associated impairment of sexual function and the devastating blow to self-image. "He was a young unmarried male," Davis says. "Where does he go from there?"

"We treat a lot of people but some make a real impact on your mind."

To urologists who have encountered urotrauma, the condition goes beyond mangled body parts to encompass various insidious consequences.

An explosion from what would normally be a safe distance might cause percussive trauma revealed long after the fact. Infertility can take years to be exposed. Veterans treated for post-traumatic stress may live with a loss of libido brought on by antidepressant drugs, which they don't want to talk about with physicians.

Longer body armour is available, Davis says, but is harder and heavier to wear. It's a balancing act in which too little protection exposes the soldier to more danger from the enemy but too much inhibits mobility. It's also of limited use against a common peril: a roadside bomb sending shrapnel up through a vehicle's floor.

Despite the incidence of improvised explosive device-related injuries to both American and Canadian soldiers, the spectrum of urogenital trauma may differ in part because of their different theatres of war - most US casualties come from
Iraq — and in part because of the roles the soldiers are playing, Tien speculates.

"If the injuries are happening for someone who is walking, you'd expect the blast to go into the scrotum or the penis," he says, referring to the more extensive injuries in American soldiers. "But if most of the events happen from being in a vehicle, you're more likely to bruise your kidney because you bounce around the inside of it."

Although the Department of National Defence will not comment on potential changes to body armour or other protective equipment, Tien did say the Canadian Forces will be watching the US study with an eye to recommendations that can help prevent urogenital injuries to Canadians. "From a young man's perspective, a devastating urogenital injury I'm sure is quite psychologically devastating," he adds.

The US Marine who needed so much blood was five days from going home from Iraq in 2007 when a sniper shot him under his vest and through his liver.

"We used all the drugs we had, all the blood we had," Davis says. "He actually survived. That guy never would have survived before."

The Marine made it home. It was up to his stateside doctors to try to make him whole. - Cal Woodward, Washington, DC and Laura Eggertson, Ottawa, Ont.

DOI:10.1503/cmaj.109-3292 (w) 